Research Article

\title{
A STUDY ON THE EXAMINATION OF THE SINTER METALLOGRAPHIC STRUCTURE
}

\section{Ömer Saltuk BÖLÜKBAŞI $I^{*}$}

Sintering process is carried out domestic and imported iron ore powders, fluxes, coke dust, metallurgical recycling powders and slag forming agents. Nowadays, in order to obtain process and operating parameters that will work with the best sinter quality, extensive researches have been made by iron and steel industry. Sinter quality parameters followed by the sinter blend loaded on the sinter strand and then granulated were examined. We can obtain chemical analysis of the phases by scanning electron microscopy (SEM) technique, but full consistency with images is not always possible and especially SFCA (silico-ferrite of calcium and aluminium) and SFCA-I phases are difficult to distinguish from each other and future studies are required in this field. The mineralogy and microstructure of the sinter plays an important role in determining the physical and metallurgical properties of the iron ore sinter. Mineralogical characterization of sinter phases; it is a complementary tool to conventional physical and metallurgical tests applied to iron ore sinter to evaluate and estimate sinter quality. Measurement techniques used in this study; optical image analysis and X-ray diffraction (XRD), scanning electron microscopy (SEM), energy distribution spectroscopy (EDS), results from raw data converted to autoquan format will be explained on the new studies on the interpretation of the Rietveld system. Depending on the measurement objectives of each technique, the quantification of the crystal phases, the relationship between the measurement results, the chemical composition of the phases and the relations between the minerals, as well as their advantages and disadvantages will be explained.

Key Words: Iron ore sinter mineralogy, agglomeration, crystal structure, SFCA, phase chemistry

\section{Introduction}

Sinter, which is formed by melting of fine iron ores and fluxes (limestone, dolomite, etc.) at high temperature $\left(950-1350^{\circ} \mathrm{C}\right)$, is the main ferrous input material of blast furnace. Iron ores constitute sinter cake compound in SFCA phase compound and in the form of glassy structure. Due to the significant effect of SFCA on sinter quality, it is the most important component of the sinter bond matrix. Sinter reactions become successful by controlling the microstructure and concentration of SFCA during the sintering process. In the current existing sinter plants, quality is monitored on the basis of small basicity $\left(\mathrm{CaO} / \mathrm{SiO}_{2}\right)$ ratio only. This study will investigate the effect of these four components $\mathrm{CaO}, \mathrm{Al}_{2} \mathrm{O}_{3}$,

\footnotetext{
${ }^{1}$ Department of Metallurgical and Materials Engineering, Iskenderun Technical University, Hatay, Turkey, (osaltuk.bolukbasi@iste.edu.tr) @https://orcid.org/0000-0002-8862-009X 
$\mathrm{Fe}_{2} \mathrm{O}_{3}, \mathrm{SiO}_{2}$ within the sintering process on the hardness, reducibility and efficiency will be investigated and establish an association.

The literature includes studies that qualitatively examined the microstructure of the sinter in general; and its chemical structure, mineralogy, morphology as well as the distribution of different mineral phase structures in the sinter matrix during the sintering process $[1,2,7]$. Sinter mineral formation mainly consists of SFCA, SFCA-I and SFCA-II phases. The key binding phases that provide strength of the material are SFCA and SFCA-I [3, 6, 12, 13]. The formation and contents of these structures vary according to the operational practices (sinter blend used, temperature, basicity, sintering time, etc.). Our study investigates the mineralogical conditions that allow for the formation of SFCA and SFCA-I phase structures which affect quality especially in the internal structure of the sinter. When the sinter blend consisting of iron ore, limestone, coke dust and flux mixture is heated in a sintering machine, dicalcium ferrite $\left(\mathrm{C}_{2} \mathrm{~F}-2 \mathrm{CaO} \cdot \mathrm{Fe}_{2} \mathrm{O}_{3}\right)$ structure is formed as the first product at $750-780{ }^{\circ} \mathrm{C}$, and then, iron oxide, SFCA and silicate phases are formed at 1220-1300 ${ }^{\circ} \mathrm{C}[4,8,14,15]$. With increased sintering temperature, dicalcium ferrites react with hematite to take the form of calcium ferrite (CF$\mathrm{CaO}_{\mathrm{Fe}} \mathrm{O}_{3}[5,10,16]$. Quartz begins to react with the SFCA-I and SFCA form at $1050^{\circ} \mathrm{C}$. SFCA-I breaks down between $1220{ }^{\circ} \mathrm{C}$ and $1240{ }^{\circ} \mathrm{C}$ and takes the form of SFCA [9, 10, 14, 20].

A study by Scarlett et al. (2004) suggests that the phase compositions in the sinter matrix structure consist of iron oxide by 35 to $60 \%$, ferrites (mostly SFCA) by 20 to $45 \%$, glassy phases by more than $10 \%$ and dicalcium silicates by more than $10 \%$. They emphasize that the bond phase morphology is typically composed of SFCA phase composition as well as iron oxides and silicates, forming the most important bond phase structure since SFCA has a major impact on the technological properties of the sinter [17, 18, 21]. Cores et al. [19, 25] consider that the technological quality of the sinter depends on the mineral phase form generated during the sintering process, and SFCA is the strongest bond phase affecting the sinter quality. During studies on the effects of ore mixtures of different compositions on sinter quality, it has been observed that the reducibility and cold strength of the sinter depends on the presence of calcium ferrite in the microstructure of the sinter [20,34]. The said studies also suggest that the form consisting of hematite cores surrounded by SFCA-I is the desired structure for high sinter quality. During the reduction reactions, the porous structure of the acicular SFCA has been proven to provide a wide surface contact to prevent spread of cracks.

Pownceby and Clout (2003) investigated the initiation of mineral compositions of the SFCA phase and the issue that $\mathrm{CF}_{3}\left(\mathrm{CaO}_{3} 3 \mathrm{Fe}_{2} \mathrm{O}_{3}\right), \mathrm{CA}_{3}\left(\mathrm{CaO}_{3} \mathrm{AI}_{2} \mathrm{O}_{3}\right)$ and $\mathrm{C}_{4} \mathrm{~S}_{3}\left(4 \mathrm{CaO} .3 \mathrm{SiO}_{2}\right)$ or $\mathrm{Fe}_{2} \mathrm{O}_{3}-\mathrm{AI}_{2} \mathrm{O}_{3}-\mathrm{CaO}$ compounds can be designed to create a link within a planar structure. In the aforementioned study, they observed the SFCA composition encountered in industrial sinter and named the SFCA forms as SFCA, SFCA-I and SFCA-II (dendritic) solid solution series [3,9,10,22]. In their study, Bristow and Waters (1991) state that SFCA affects the grain structure of the sinter matrix by stabilizing a fine porosity during a reduction in the initial reduction phase. They noticed that the SFCA content in the sinter structure has a maximum effect on the increase of reducibility. They studied on the association between the availability of SFCA and hematite in the sinter cake and maximum reducibility $[9,27,28,29]$.

Industrially produced iron ore sinters include two types of SFCA categorized in the literature based on the composition, morphology and crystal structure of the SFCA phase structure in iron ore. SFCA, which is the first type of these phases in the sintered material is found in the composition of $\mathrm{M}_{14} \mathrm{O}_{20}$ stoichiometry and $\mathrm{Ca}^{+2}{ }_{2.3} \mathrm{Mg}^{+2}{ }_{0.8} \mathrm{Al}^{+3}{ }_{1.5} \mathrm{Fe}^{+3}{ }_{8.3} \mathrm{Si}^{+4}{ }_{1.1} \mathrm{O}^{-2}{ }_{20}$, and the second type SFCA-I is found in the composition of $\mathrm{M}_{20} \mathrm{O}_{28}$ stoichiometry and $\mathrm{Ca}^{+2}{ }_{3.18} \mathrm{Fe}^{+3}{ }_{15.48} \mathrm{Al}^{+3}{ }_{1.34} \mathrm{O}^{-2}{ }_{28}$ [2,3]. Sinter material differs from chemical composition depending on the raw material used, process conditions and production 
conditions. The chemical morphology and element structure of the sintered material, which has a heterogeneous structure, can vary depending on the raw material supply system and process conditions [11-16, 31, 33]. The impact of the SFCA and SFCA-I phases on the formation mechanisms and the formation of a number of sintering parameters have recently been partially done by few studies [19, 23 25, 32]. However, the SFCA phase within the sinter has a significant impact on the improvement of sinter quality parameters such as TI (Tumbler index / cold strength), RDI (Reduction degradation index / hot strength), RI (Reduction index / reduction property) and RUL (Reduction under load) (26, 27, 30).

Sintering plants in the integrated iron and steel plants in our country (İskenderun Iron and Steel Works Co. / İSDEMIR, Ereğli Iron and Steel Works Co. / ERDEMIR and Karabük Iron and Steel Works Co. / KARDEMIR) monitor quality on the basis of small basicity $\left(\mathrm{CaO} / \mathrm{SiO}_{2}\right)$ ratio only. The total annual sinter production of these plants exceeds 11 million tons. However, what is important in determining the quality in the sintering process is the fact that the changes in ferrite structures, wustite $(\mathrm{FeO})$ and aluminate cannot be monitored since no common monitoring method could be developed yet. By controlling the SFCA (silico-ferrite calcium and aluminium) structure in the sintered structure, this quaternary phase matrix $\left(\mathrm{CaO}, \mathrm{Al}_{2} \mathrm{O}_{3}, \mathrm{Fe}_{2} \mathrm{O}_{3}, \mathrm{SiO}_{2}\right)$ will be taken under control and all parameters that may affect the quality of the process will be examined. All compounds in the sinter matrix must be evaluated individually using the Rietveld method $\left(\mathrm{Fe}_{2} \mathrm{O}_{3}, \mathrm{Fe}_{3} \mathrm{O}_{4}, \mathrm{Ca}_{2} \mathrm{SiO}_{4}, \mathrm{SFCA}\right.$, SFCA-I) to know the quantitative contents of existing phase structures. Data obtained after determination of SFCA quantity in the sintered material will be associated with other quality parameters monitored (Basicity, RDI, mineralogical, etc.) and performance data coming from blast furnaces to increase the usage efficiency of the sinter and consequently reduce the raw material costs.

\section{Material and Method}

Sinter is an important blast furnace input material formed by adding 0-10 $\mathrm{mm}$ iron ores and fluxes which cannot be charged directly to the blast furnaces and limestone powder, dolomite, olivine, coke dust, return dust and waste materials (chimney dust, steelmaking slag, mill scale, gas cleaning sludge of blast furnace and steelmaking) in certain proportions without being completely melted, which are heated to $950-1350{ }^{\circ} \mathrm{C}$ so as to adhere to each other due to superficial melting. The flow chart of a typical industrial sinter plant is displayed in Figure 1. During the sintering process, the combustion that starts in the sinter furnace moves from the surface of the blend laid on the sinter strand to its base, and the surfaces of the particles in the combustion zone reach the melting temperature, and the gangue components form a semi-liquid slag, the moisture in the blend evaporates, the carbonates decompose, the sulphurous compounds oxidize and their sulphur burns away from the system.

The internal structure of the sinter consists of the composition of iron ores in the sintering process, SFCA and dicalcium silicate, and glassy structure. The reactions that occur also regulate the volume fraction of each mineral that may affect the quality of the sinter, thus the performance of the blast furnace. SFCA is considered to be the most important component of the sinter bond matrix since it affects sinter quality significantly if the content of SFCA in sintered iron ore is high. Sinter reactions become successful by controlling the microstructure and concentration of SFCA during the sintering process. In this study, sample variety was provided by producing at different operating parameters with a laboratory type sintering machine in order to be able to perform more rapid test studies from iron ore blends prepared in different compositions. In sinter production, domestic and imported iron ores are mixed with certain proportions of fluxes (limestone, dolomite, etc.) and fuel (coke dust) to produce sinter in the basicity values of 1.6-2.0 $\left(\mathrm{CaO} / \mathrm{SiO}_{2}\right)$ and at different operating parameters. Ratios of 
imported iron powder and domestic iron powder to be used in the sinter blend will vary between 50 $70 \%$ and between $30-50 \%$, respectively depending on operating and laboratory practices. The content of fluxes to be used in the sinter blend will be in the range of 7 to $9 \%$ depending on the acidic compounds such as $\mathrm{SiO}_{2}$ and $\mathrm{Al}_{2} \mathrm{O}_{3}$.

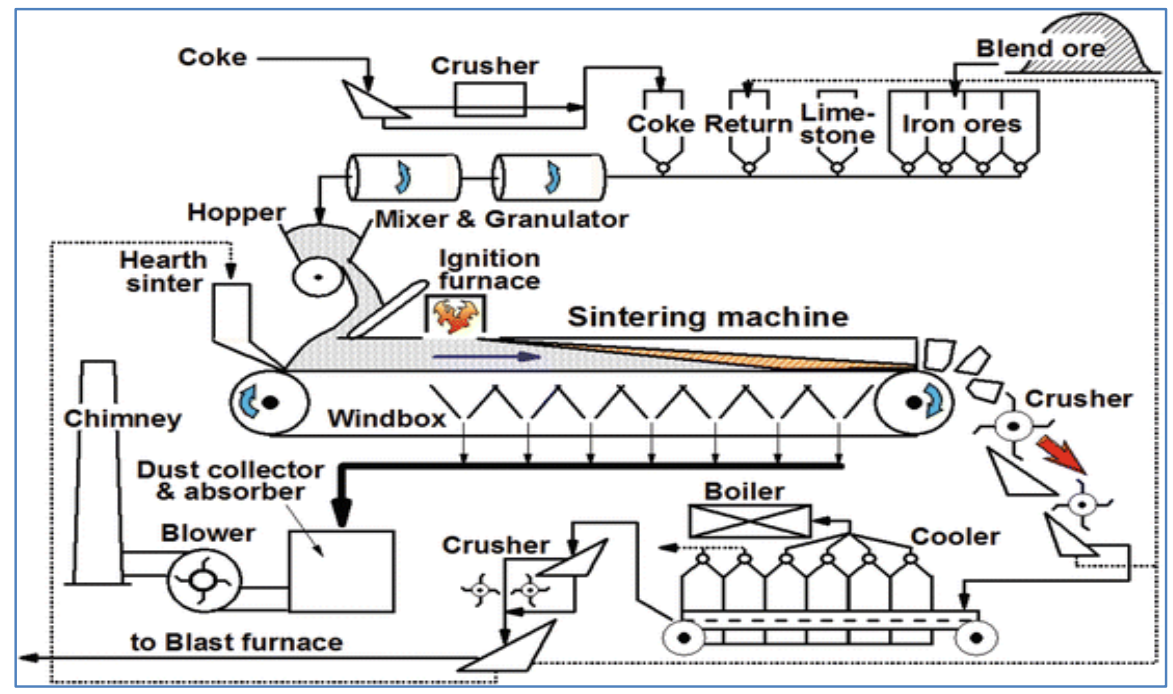

Figure 1. Typical flow chart of industrial type sinter production [35].

Sinter blend samples were prepared in accordance with the following parameters; - Consumption of coke dust. It will vary between $6 \%$ and $7 \%$ in the blend depending on the sintering temperature.

- Humidity of the raw material: 7-8\%.

- Ignition temperature: $1000 \sim 1200{ }^{\circ} \mathrm{C}, 1$ minute ignition negative pressure: $5660 \mathrm{~Pa}$.

- Negative pressure for sinter: $10.850 \mathrm{~Pa}$.

\section{Experimental Studies and Comments}

\subsection{SEM and XRD Studies on Sinter Samples}

Given the increasing importance and studies in directing the sinter production quality according to the SFCA content in the sinter phase structure in addition to the existing physical and chemical quality monitoring tests of the sinter, which is an important input material in blast furnace process control; determination of ideal SFCA will help to control all sintering para meters of the sinter, which is the main input material of the blast furnace process in iron and steel plants. Thus, besides the cost advantage to be created by a better process control by charging more stable sinter to the Blast Furnace, a new iron production quality monitoring will be provided for the iron and steel industry on a global scale. Quadruple bond SFCA phase has been accepted as a main parameter in the sintering process by scientists since it significantly affects the technological quality of the sinter including high mechanical hardness (TI, RI and RDI, etc.), but it has not been sufficiently studied yet. Studies conducted on the effects of microstructure and mineral composition on the crack resistance of the sinter noticed that SFCA-I (especially acicular SFCA) is the main material affecting the spreading resistance of cracks. It has been observed that the acicular SFCA type of porous structure provides a greater reaction area in solid-gas contact, thereby increasing the reducibility in the blast furnace, shortening the processing time and saving fuel (metallurgical coke) and time. 

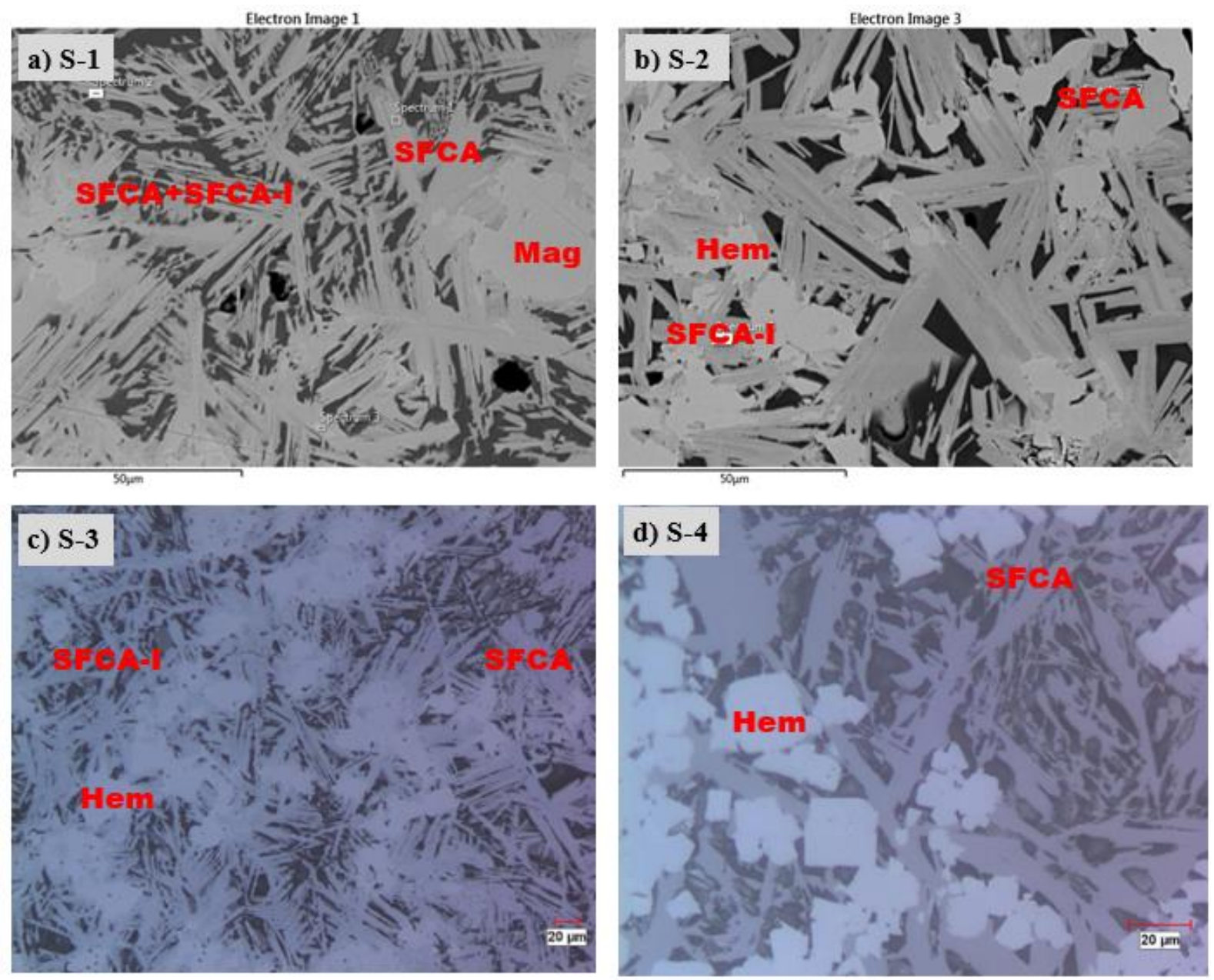

Figure 2. Sinter sample a) S-1 and b) S-2 SEM images, c) S-3 and d) S-4 optical microscope images (Hem: Hematite, Mag: Magnetite, SFCA, SFCA-I (X500)

SEM and optical microscope studies were performed with 500X magnification on sinter samples. The presence of SFCA and SFCA-I phase structures in the sinter matrix varies depending on the sintering temperature, blend ignition time and furnace temperature. The SEM and optical microscope images of the sinter samples are indicated in Figure 2.

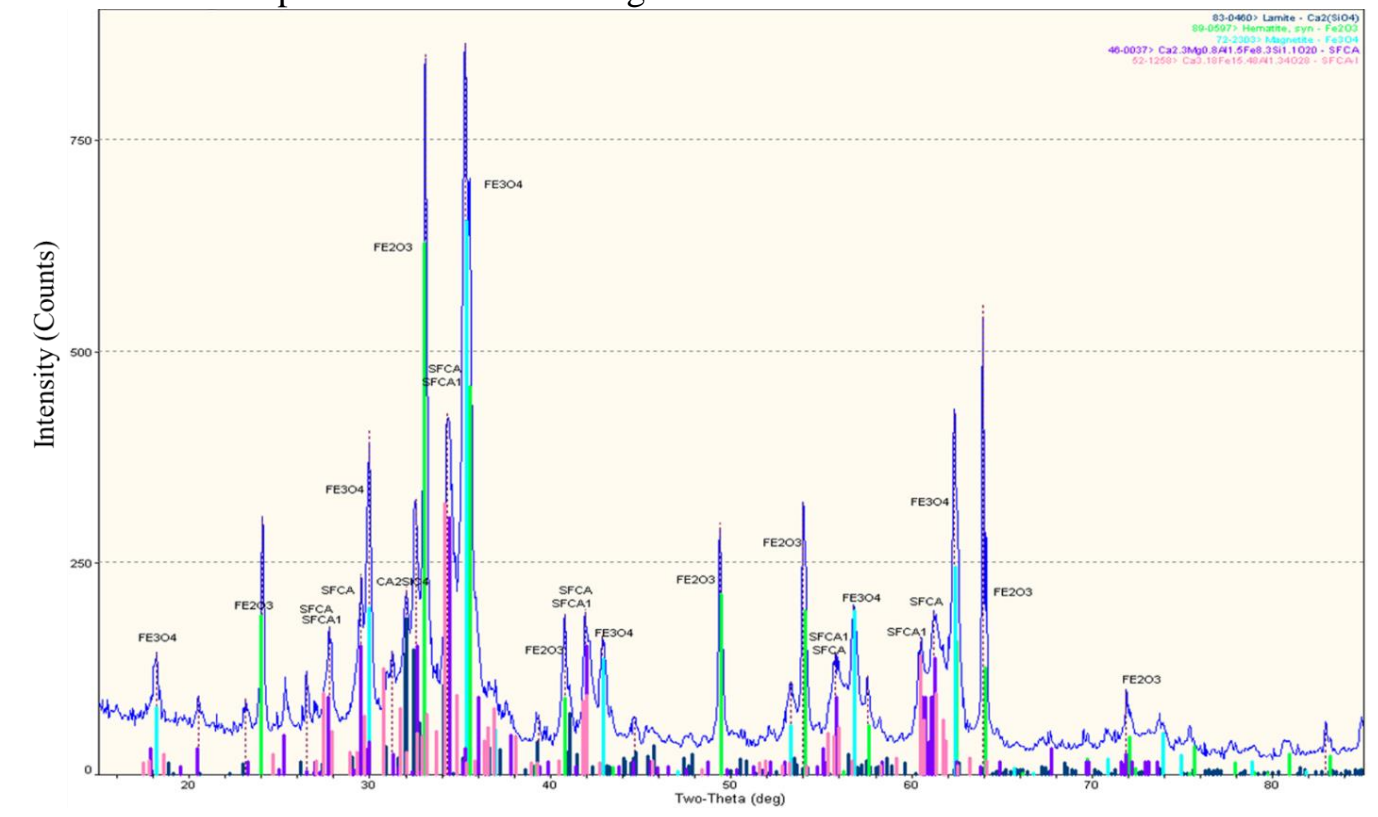

Figure 3. Sinter sample XRD phase analysis diagram. 
XRD phase diagram was demonstrated in Figure 3. During the XRD studies conducted, $\mathrm{Fe}_{2} \mathrm{O}_{3}$ (hematite), $\mathrm{Fe}_{3} \mathrm{O}_{4}$ (magnetite), $\mathrm{FeO}$ (wustite), $\mathrm{SiO}_{2}$ (quartz), $\mathrm{Ca}_{2} \mathrm{SiO}_{4}$ (larnite), $\mathrm{CaO}$ (lime), and $\mathrm{XRD}$ device printouts for SFCA and SFCA-I phases are quantitatively determined with the help of the Rietveld Method. The composition information of SFCA and SFCA-I phases stoichiometrically is demonstrated in Table 1.

Table 1. Stoichiometric composition information of SFCA and SFCA-I phases

\begin{tabular}{|c|c|c|c|c|c|c|c|c|}
\hline & $\mathbf{F e}^{+3}$ & $\mathbf{F e}^{+2}$ & $\mathbf{F e}$ & $\mathbf{A l}$ & $\mathbf{C a}$ & $\mathbf{M g}$ & $\mathbf{S i}$ & $\mathbf{M n}$ \\
\hline $\begin{array}{c}\text { SFCA } \\
\left(\mathbf{M}_{\mathbf{1 4}} \mathbf{O}_{\mathbf{2 0}}\right)\end{array}$ & 10.18 & 0.90 & 11.08 & 0.50 & 1.85 & 0.17 & 0.49 & 0.08 \\
\hline $\begin{array}{c}\text { SFCA-I } \\
\left(\mathbf{M}_{\mathbf{2 0}} \mathbf{O}_{\mathbf{2}}\right)\end{array}$ & 14.36 & 1.72 & 16.08 & 0.38 & 3.48 & 0.21 & 0.05 & 0.38 \\
\hline
\end{tabular}

\subsection{The Study of Rietveld Method and Autoquan Program on the Sinter Samples}
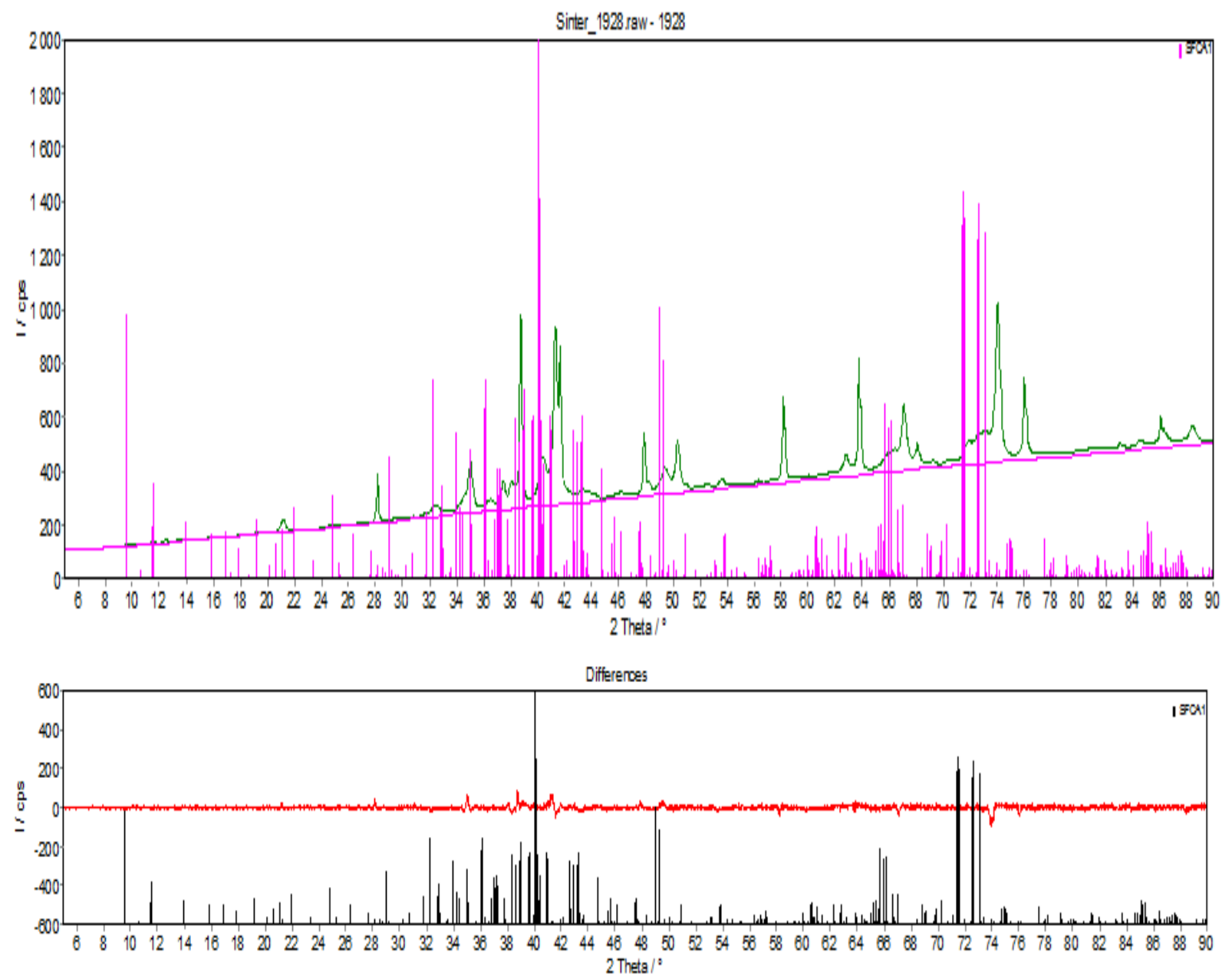

Figure 4. Rietveld (refinement) image of the sinter sample.

The phase structures in the sinter were determined using XRD devices with X-Ray tubes that irradiates $\mathrm{Cu} \mathrm{K}$-alpha and $\mathrm{Co} \mathrm{K}$-alpha. The scanning process was done between $5-90^{\circ}$ at the scanning speed of 2 degree/min. Crystal data phase files with *.XRDML extension of sinter samples is created in XRD device and these files are converted to files with *.RD extension by PANalytical X'Pert Highscore Plus software program. In this file, the files are converted to *.RAW files using ConVX.exe program and opened with the Autoquan program having the crystal data files of the related phases. 
Autoquan program and the rietveld method can be used to determine the individual percentage of all phases in the sinter structure. Data on quantitative contents of existing phase structures is obtained from the study conducted by this method. The XRD drawing of a typical sinter material is given in Figure 4. The position of the peaks obtained from the crystal structure of the sinter is shown as a vertical line. For example, the hematite mineral content in the sinter material can be easily identified and measured by XRD with an approximately 12 minute scan. Rietveld image of the sinter sample was indicated in Figure 4. When using powder XRD with mineral compositions obtained by SEM analysis, much information can be obtained about the element distribution in various minerals. The advantage of this method over other methods is to more accurately determine phase contents (\%) by using the information content of the diffractogram better.

Before the raw data obtained were evaluated in Autoquan, the conditions of the relevant device were kept available in the device file. This step was important for a proper refinement process. However, the XRD convert program used to convert the raw data format to Autoquan format is given in Figure 5.

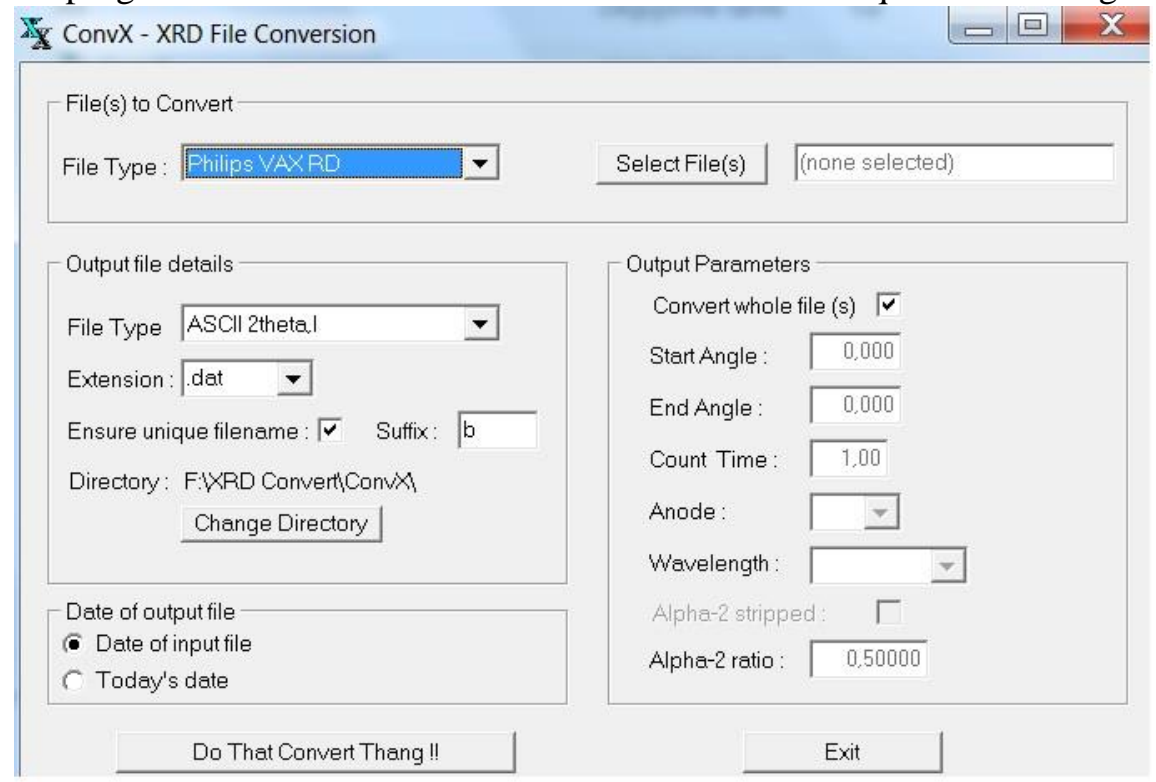

\section{Figure 5. XRD convert program}

Figure 5 indicates charts containing the results of quantitative phase measurements using Autoquan with an X-Ray tube that radiates $\mathrm{Cu} \mathrm{K}$-alpha and Co K-alpha. Different SFCA values were found in the same samples subjected to $\mathrm{Cu} \mathrm{K}$-alpha and $\mathrm{Co} \mathrm{K}$-alpha analysis. According to the results obtained with the tube that radiates $\mathrm{Cu} \mathrm{K}$-alpha during the investigation of the phase structures of the sinter materials, since the incident ray is absorbed due to the fluorescence and absorption effect, especially in iron-containing materials, the intensity/counts sensitivity values were quite low, so no healthy results could be obtained. In order to determine the phase structures in the sinter, XRD device with X-Ray tube that radiates Co K-alpha, which can make more precise measurements in ironcontaining phases, was preferred. After the sample size was grinded to 20 microns, it was scanned at 30 $\mathrm{kV}$ and $35 \mathrm{~mA}$ in the XRD device. Figure 6 reveals the quantitative (\%) sinter phase results of the structures in the internal morphology of the sinter sample, obtained by Rietveld analysis performed via the Autoquan program using XRD device with $\mathrm{Cu} \mathrm{K}$-alpha and $\mathrm{Co} \mathrm{K}$-alpha radiation on the sinter samples. 

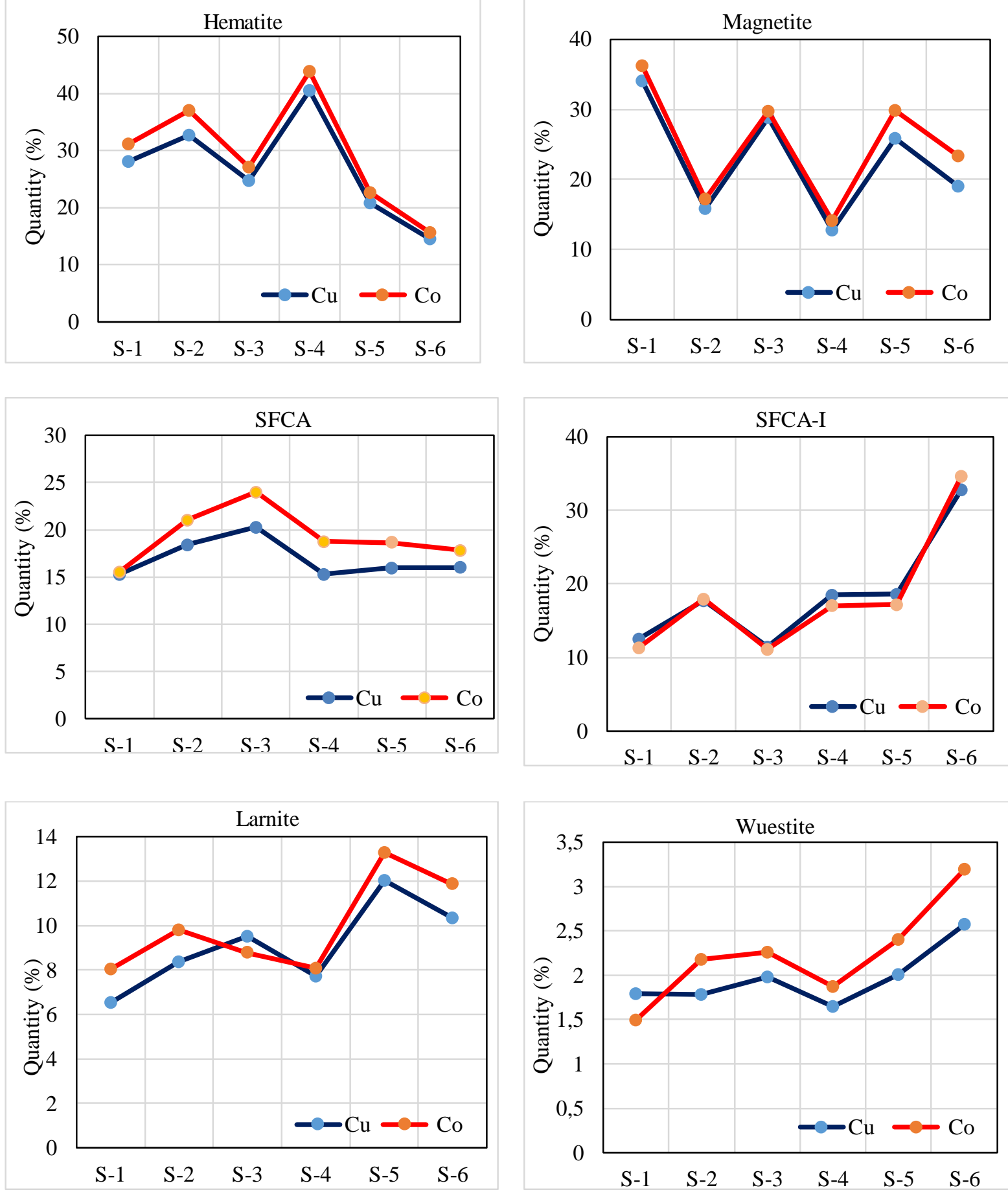

Figure 6. Rietveld analysis quantitative sinter phase results by XRD device with $\mathrm{Cu}$ K-alpha and Co Kalpha radiation.

Using the rietveld method, all compounds in the sinter matrix are evaluated individually ( $\mathrm{FeO}$, $\mathrm{Fe}_{2} \mathrm{O}_{3}, \mathrm{Fe}_{3} \mathrm{O}_{4}, \mathrm{Ca}_{2} \mathrm{SiO}_{4}$, SFCA, SFCA-I, etc.) to know about the quantitative contents of the existing phase structures. The Rietveld method utilizes the relative weight ratios of all phase crystals included in the model better and helps the determination of more accurate phase quantities (as \%), and results are achieved quantitatively and quickly in a few minutes without the need for standard or calibration [22, 30, 31]. It also facilitates the interpretation of sinter phase data and the regular protection of phases. The Autoquan program supports the analytical listing of SFCA phase results from the sinter sample and 
transferring the results to standard applications. Thanks to this program, changes that may occur in the sinter structure or process conditions can be tracked more accurately with the SFCA data.

\section{Conclusion}

All-important parameters in the sinter material, which affect the quality of the sintering process are examined in order to make the sintering process more stable with a detailed internal structure analysis. The changes shown by the structures within the sinter matrix structure, especially SFCA, SFCA-I and SFCA-II phase structures, which have a great effect on the physical and metallurgical properties of the sinter, depending on the sintering temperature, time, raw material type and basicity are followed by Autoquan program and Rietveld method, and the process and raw material conditions required for the full control of the sinter mineral formation are determined to create more durable sinter production and process monitoring systematics. Within the scope of this study, it will be possible to use the data to be obtained with the XRD device to quantify the phase structures formed in the sinter produced using the related software. In this context, it is important to make a correlation with the physical properties of the material, especially the ones that affect the strength of the material, by following up the ratio of iron oxides formed during the process to the SFCA phase structures. The result of the study is reduction in the return dust contents as a result of the production of high-strength sinter, and the valuation of such fine dusts in the blast furnace to provide significant savings in ore consumption. Utilization of an X-Ray tube that radiates Co K-alpha, which can make more precise measurements in iron-containing phases for investigation of the sinter phase structure, is important due to the fluorescence effect at more intensive values.

\section{Acknowledgements}

This manuscript is written with the research study numbered 1059B191401374 supported by 2219 Research Scholarship and Supports Directorate (BIDEB) of The Scientific and Technological Research Council of Turkey (TUBITAK). I am grateful to TUBITAK for assistance.

\section{References}

[1] Zöll, K., Kahlenberg, V., Krüger, H., \& Tropper, P. (2018). Investigations on FCAM-III (Ca2. $\left.{ }_{38} \mathrm{Mg}_{2 .}{ }_{09} \mathrm{Fe}^{3+} 10.61 \mathrm{Fe}^{2+} 1.59 \mathrm{Al}_{9.33} \mathrm{O}_{36}\right)$ : A new homologue of the aenigmatite structure-type in the system CaO-MgO-Fe $2 \mathrm{O}_{3}-\mathrm{Al}_{2} \mathrm{O}_{3}$. Journal of Solid State Chemistry, 258, 307-319.

[2] Hsieh, L.H., Whiteman, J.A. (1989). Effect of oxygen potential on mineral formation in lime-fluxed iron ore sinter. ISIJ International, 29(8), 625-634.

[3] Kama, M., Miyazaki, T., Ito, K., Hida, Y., Sasaki, M. (1984). Morphological Analysis of Calcium Ferrite and Hematite in Sintered Ore. (Synopsis). Trans. Iron Steel Inst. Jpn., 24(10).

[4] Liu, D., Loo, C. E., Evans, G. Liu, D., Loo, C. E., Evans, G. (2016). Flow characteristics of the molten mix generated during iron ore sintering. International Journal of Mineral Processing, 149, 56-68.

[5] Pownceby, M. I., \& Patrick, T. R. (2000). Stability of SFC (silico-ferrite of calcium) solid solution limits, thermal stability and selected phase relationships within the $\mathrm{Fe}_{2} \mathrm{O}_{3}-\mathrm{CaOSiO}_{2}$ (FCS) system. European Journal of Mineralogy, 12(2), 455-468.

[6] Young, R.A. (1993). The Rietveld method, International Union Crystallography, Oxford University Press, Oxford, (Vol. 5, pp. 1-38).

[7] Dawson, P.R., Ostwald, J., Hayes, K.M. (1984). The influence of the sintering temperature profile on the mineralogy and properties of iron ore sinters. In AIMM Bull. Proc. (Vol. 289, No. 5, pp. 163-169).

[8] Wei, R., Lv, X., Yang, M., Xu, J.,You, Z. (2018). Improving the property of calcium ferrite using 
a sonochemical method. Ultrasonics sonochemistry, 43, 110-113.

[9] Ding, X., Guo, X. M. 2016. Study of $\mathrm{SiO} 2$ involved in the formation process of silico-ferrite of calcium (SFC) by solid-state reactions. International Journal of Mineral Processing, 149, 69-77.

[10] De Magalhaes, M.S., Brandao, P. R. G. (2003). Microstructures of industrial sinters from Quadrilatero Ferrifero's iron ores, Minas Gerais State, Brazil. Minerals Engineering, 16(11), 1251 1256.

[11] Scarlett, N.V., Pownceby, M.I., Madsen, I.C., Christensen, A.N. (2004). Reaction sequences in the formation of silico-ferrites of calcium and aluminum in iron ore sinter. Metallurgical and materials transactions B, 35(5), 929-936.

[12] Webster, N. A., Churchill, J. G., Tufaile, F., Pownceby, M. I., Manuel, J. R., Kimpton, J. A. 2016. Fundamentals of silico-ferrite of calcium and aluminium (SFCA) and SFCA-I iron ore sinter bonding phase formation: effects of titanomagnetite-based iron sand and titanium addition. ISIJ International, 56(10), 1715-1722.

[13] Koryttseva, A., Webster, N. A., Pownceby, M. I., Navrotsky, A. (2017). Thermodynamic stability of SFCA (silico- ferrite of calcium and aluminum) and SFCA- I phases. Journal of the American Ceramic Society, 100(8), 3646-3651.

[14] Cai, B., Watanabe, T., Kamijo, C., Susa, M., \& Hayashi, M. (2018). Comparison between Reducibilities of Columnar Silico-ferrite of Calcium and Aluminum (SFCA) Covered with Slag and Acicular SFCA with Fine Pores. ISIJ International, 58(4), 642-651.

[15] Webster, N. A., Pownceby, M. I., \& Pattel, R. (2017). Fundamentals of silico-ferrite of calcium and aluminium (SFCA) and SFCA-I iron ore sinter bonding phase formation: effects of mill scale addition. Powder Diffraction, 32(S2), 85-89.

[16] Cores, A., Babich, A., Muñiz, M., Ferreira, S., Mochon, J. (2010). The influence of different iron ores mixtures composition on the quality of sinter. ISIJ International, 50(8), 1089-1098.

[17] Pownceby, M.I., Clout, J.M.F. (2003). Importance of fine ore chemical composition and high temperature phase relations: applications to iron ore sintering and pelletising. Mineral Processing and Extractive Metallurgy, 112(1), 44-51.

[18] Bristow, N.J., Waters, A.G. (1991). Role of SFCA in promoting high-temperature reduction properties of iron ore sinters. Transactions of the Institution of Mining and Metallurgy, Section C, 100.

[19] Mumme, W.G., Clout, J.M.F. \& Gable, R.W. (1988). The crystal structure of SFCA-I Ca3.18Fe ${ }^{3+}$ $14.66 \mathrm{Al}_{1.34} \mathrm{Fe}^{2+} 0.82 \mathrm{O}_{28}$, a homologue of the aenigmatite structure type, and new structure type, and new crystal refinements of b-CCF, Ca2.99 $\mathrm{Fe}^{3+} 14.30 \mathrm{Fe}^{2+} 0.55 \mathrm{O}_{25}$ and $\mathrm{Mg}$-free SFCA, Ca2.45 $\mathrm{Fe}^{3+}$ 9.04 $\mathrm{Al}_{1.74} \mathrm{Fe}^{2+} 0.16 \mathrm{Si}_{0.6} \mathrm{O}_{20}$. Neues Jahrbuch Mineralogie-Abhandlungen, 173(1), 93.

[20] Mumme W.G. (2003). The crystal structure of SFCA-II, Ca5.1Al9.3 $\mathrm{Fe}^{3+} 14.30 \mathrm{Fe}^{2+} 0.55 \mathrm{O}_{48}$, a new homologue of the aenigmatite structure-type, and structure refinement of SFCA, $\mathrm{Ca}_{2} \mathrm{Al}_{5} \mathrm{Fe}_{7} \mathrm{O}_{20}$. Implications for the nature of the. Neues Jahrbuch für Mineralogie-Abhandlungen: Journal of Mineralogy and Geochemistry, 178(3), 307-335.

[21] Bhagat R.P., Chattoray, U., SIL, S.K. (2006). Porosity of sinter and its relation with the sintering indices, ISIJ International, 46(11), 1728-1730.

[22] T. van den Berg and J.P.R. de Villiers: T. I. Min. Metall. C, 2009, vol. 118, pp. 214-21.

[23] Sasaki, M., Hida, Y., (1982). Considerations on the properties of sinter from the point of sintering reaction. Tetsu to Haganè 68, 563-571.

[24] McAndrew, J., Clout, J.M.F., (1993). The nature of SFCA and its importance as a bonding phase in iron ore sinter. In Proceedings of the 4th China-Australia Symposium on the Technology of Feed Preparation for Ironmaking, Dampier, pp. 1-15.

[25] Chaigneau, R. (1994). Fluxed sinter formation and SFCA reduction under Simulated Conditions, $\mathrm{PhD}$ Thesis, Delft University Press, p. 12-28.

[26] Liles, D. C., de Villiers, J. P., Kahlenberg, V. 2016. Refinement of iron ore sinter phases: a silicoferrite of calcium and aluminium (SFCA) and an Al-free SFC, and the effect on phase quantification by X-ray diffraction. Mineralogy and Petrology, 110(1), 141-147.

[27] Bölükbaşi Ö.S. (2015). Determination of Ideal SFCA (silico-ferrite-calcium-aluminum) Phase 
Structure in Iron Ore Sintering Process, TÜBİTAK Research (1059B191401374) 1. Report Result. [28] Ishikawa, Y., Shimomura, Y., Sasaki, M., Toda, H. (1983). Improvement of sinter quality based on the mineralogical properties of ores. Ironmaking Proceedings. vol. 42. p. 17-29.

[29] Hancart, J., Leroy, V., Bragard, A. (1967). A study of the phases present in blast furnace sinter. Some considerations on the mechanism of their formation. CNRM Metall. Report, 3-7.

[30] Patrick, T. R., \& Pownceby, M. I. (2002). Stability of silico-ferrite of calcium and aluminum (SFCA) in air-solid solution limits between $1240^{\circ} \mathrm{C}$ and $1390^{\circ} \mathrm{C}$ and phase relationships within the $\mathrm{Fe}_{2} \mathrm{O}_{3}-\mathrm{CaO}-\mathrm{Al}_{2} \mathrm{O}_{3}-\mathrm{SiO}_{2}$ (FCAS) system. Metallurgical and Materials Transactions B, 33(1), 79-89.

[31] Garbers-Craig, P. C., JMA, J. W. (2003). The influence of increased air flow on the spatial variation of iron sinter quality. Journal of the Southern African Institute of Mining and Metallurgy, 103(10), 645-650.

[32] Wei, R., Lv, X., Yang, M., Xu, J., \& You, Z. (2018). Improving the property of calcium ferrite using a sonochemical method. Ultrasonics sonochemistry, 43, 110-113.

[33] Scarlett, N. V., Madsen, I. C., Pownceby, M. I., Christensen, A.N. (2004). In situ X-ray diffraction analysis of iron ore sinter phases. Journal of Applied crystallography, 37(3), 362-368.

[34] Kalenga, M.K. (2008). Investigation into the influence of magnesia content, alumina content, basicity and ignition temperature on the mineralogy and properties of iron sinter. Doctoral dissertation, University of Pretoria, Pretoria, Republic of South Africa, 25-27.

[35] Komarov S.V., Kasai E. (2004). Simulation of sintering of iron ore packed bed with variable porosity. Institute of Multidisciplinary Research for Advanced Materials. Phoenics User Conference, Melbourne, Australia, 25-30. 